\title{
LATIN CURSE TEXTS: MEDITERRANEAN TRADITION AND LOCAL DIVERSITY
}

\begin{abstract}
Summary: There are altogether about six hundred Latin curse texts, most of which are inscribed on lead tablets. The extant Latin defixiones are attested from the $2^{\text {nd }}$ cent. BCE to the end of the $4^{\text {th }}$ and beginning of the $5^{\text {th }}$ century. However, the number of extant tablets is certainly not final, which is clear from the new findings in Mainz recently published by Blänsdorf (2012, 34 tablets), ${ }^{1}$ the evidence found in the fountain dedicated to Anna Perenna in Rome 2012, (26 tablets and other inscribed magical items), ${ }^{2}$ or the new findings in Pannonia (Barta 2009). ${ }^{3}$ The curse tablets were addressed exclusively to the supernatural powers, so their authors usually hid them very well to be banished from the eyes of mortals; not to speak of the randomness of the archaeological findings. Thus, it can be assumed that the preserved defixiones are only a fragment of the overall ancient production. Remarkable diversities in cursing practice can be found when comparing the preserved defixiones from particular provinces of the Roman Empire and their specific features, as this contribution wants to show.
\end{abstract}

Key words: Curses with their language, formulas, and content representing a particular Mediterranean tradition documented in Greek, Latin, Egyptian Coptic, as well as Oscan curse tablets, Latin curse tablets, curse taxonomy, specific features of curse tablets from Italy, Africa, Britannia, northern provinces of the Roman Empire

There are about 1600 defixiones known today from the entire ancient world dated from the $5^{\text {th }}$ century BCE up to the $5^{\text {th }}$ century $\mathrm{CE}$, which makes a whole millennium. The

${ }^{1}$ BlÄnsdorf, J.: Die defixionum tabellae des Mainzer Isis- und Mater Magna-Heiligtums. Defixionum tabellae Mogontiacenses [DTM]. Mainz 2012.

2 See n. 7.

${ }^{3}$ See BARTA, A.: The Language of Latin Curse Tablets from Pannonia. A new Curse tablet from Aquincum. Acta Ant. Hung. 49 (2009) 23-29. See also BARTA, A.: Milites magistratusque. A new curse tablets from Savaria. ACD IIL (2012) 167-173; and BARTA, A.: Ito pater, Eracura and the Messenger. A preliminary Report on a new curse tablet from Aquincum. ACDLI (2015) 101-103. See also BARTA, A.: New Remarks on the Latin Curse Tablet from Savaria. Hungarian Polis Studies 22 (2016) 63-69, and the paper of the same author present in this volume: A Letter to the Underworld a Research Report on the curse Tablet Aq-2, pp. 45-56. 
Magdeburg university project headed by prof. Martin Dreher prepared an exhaustive database called TheDeMa (Thesaurus Defixionum Magdeburgensis) which contain an online corpus of all extant defixiones, including photos, facsimiles, translations, commentaries and a relevant bibliography.

There are altogether about six hundred Latin curse texts ${ }^{4}$ most of which are inscribed on lead tablets. The extant Latin defixiones are attested from the $2^{\text {nd }}$ cent. BCE to the end of the $4^{\text {th }}$-beginning of the $5^{\text {th }}$ century CE. The preserved Greek curse tablets from the $5^{\text {th }}$ cent. BCE found in Sicily and the Oscan tablets dated to the $4^{\text {th }}$ or $3^{\text {rd }}$ cent. BCE indicate that a Latin cursing tradition could have existed at the same time but the tablets, unfortunately, did not preserve.

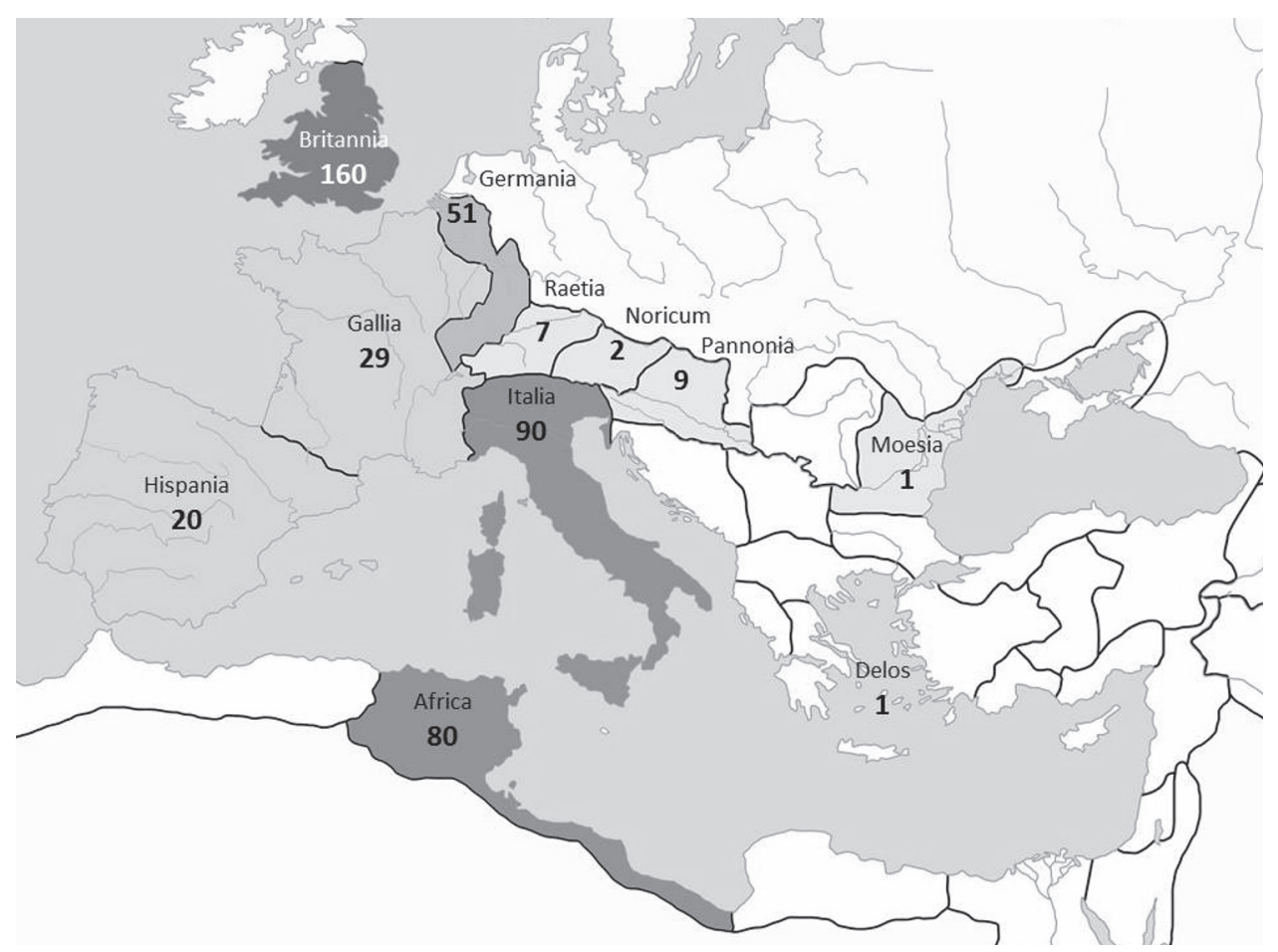

Picture 1. Distribution of published Latin defixiones in the Roman Empire

The map shows the numbers of extant published tablets found in the western provinces of the Roman Empire. More than 270 tablets have been found in Britannia - the excavations carried out in Britain in 1970s and 1980s uncovered a huge number of tablets coming predominantly from the excavations taking place in the sacred

${ }^{4}$ The number of Greek defixiones exceeds one thousand and they date back as early as to the $5^{\text {th }}$ century BCE, see FARAONE, CH. A.: The Agonistic Context of Early Greek Binding Spells. In FARAONE, CH. A. - ObBinK, D. (eds.): Magika Hiera. Ancient Greek Magic and Religion. Oxford 1991, 3-32, here 4. 
precinct dedicated to Mercury in Uley, ${ }^{5}$ and in the thermal springs and the adjacent temple of Minerva Sulis in the city of Bath. ${ }^{6}$ However, many of these are damaged to a large extent or unintelligible, 160 tablets have been published, out of which about 100 contain only slightly disrupted continuous texts. About 90 tablets come from Italy, including the most recent evidence found in the fountain dedicated to Anna Perenna in Rome, these are 26 tablets $^{7}$ and other inscribed magical items. Finally, new findings in Mainz were recently published by Blänsdorf (34 tablets). ${ }^{8}$ A large number of tablets have also been found in Africa, many of which were made by professional magicians. The evidence from Hispania, Gallia, and Pannonia is not so extensive.

As already known, defixiones were intended to affect the actions or health of people or animals against their will ${ }^{9}$ and with the help of supernatural powers. Therefore, curse tablets are closely linked to the field of magic, which is inseparably bound to ancient religion.

Any attempt to classify the multifaceted inventory of Greek and Latin cursing formulas is inevitably impeded by several problematic issues. ${ }^{10}$ Texts that have preserved so far differ not only in age and provenance, but also include the different, more or less complex, types of curses. Furthermore, author's erudition played its role; as well - the preserved corpus includes the curses made by professional magicians, as well as the more or less amateurish attempts of laymen. Generally, Latin curses usually consist of the following distinctive features: The names of cursed persons in the nom. or acc. (eventually, a patronymic or metronymic), the predicates (of cursing or handing over - defigo, trado), and/or the object in the accusative (list of cursed persons or objects, mostly body parts), as well as the names of gods and daemons appealed to (Proserpine, Pluto, etc.). Moreover, these texts sometimes act upon analogies, using the so-called simile-formula which is based on the analogy expressed by the wish that the victim becomes similar to something he/she differs from, or happens to be in a situation different from his/her recent condition. For example, the victim of the curse cited below is

${ }^{5}$ See Tomlin, R. S. O.: The Inscribed Lead Tablets: An Interim Report. In WoOdWARD, A. LEACH, P. (edd.). The Uley Shrines. Excavation of a Ritual Complex on West Hill, Uley, Gloucestershire, 1977-1979. Oxford 1993, 112-130.

${ }^{6}$ See Tomlin, R. S. O.: The Curse Tablets. In B. Cunliffe (ed.): The Temple of Sulis Minerva at Bath. Vol. 2: The Finds from the Sacred Spring. Oxford 1988, 59-270.

${ }^{7}$ Published by J. Blänsdorf and M. Piranomonte, see BlänSDORF, J. - PirAnOMOnTE, M.: Schede di catalogo IX 49. 3-6, IX 49. 8-28. In Friggeri, R. - Granino CECERE, M. G. - Gregori, G. L. (eds.): Terme di Diocleziano. La collezione epigrafica. Milano 2012, 617-639. See also BLÄNSDORF, J.: The Social Background of the defixion Texts of Mater Magna at Mainz and Anna Perenna at Rome. InPIRANOMONTE, M. - Simón, F. M. (eds.): Contesti magici. Roma 2012, 147-160. See also Piranomonte, M.: Un contesto magico straordinario. In PIRANOMONTE-SIMÓN 161-174.

${ }^{8}$ See BLÄNSDORF: Die defixionum tabellae (n. 1).

${ }^{9}$ See the exact definition of Jordan: "Defixiones, more commonly known as curse tablets, are inscribed pieces of lead, usually in the form of small, thin sheets, intended to influence, by supernatural means, the actions or the welfare of persons or animals against their will." JORDAN, D. R.: Defixiones from a Well Near the South-West Corner of the Athenian Agora. Hesperia 54.3 (1985) 205-255.

${ }^{10}$ See also Urbanová, D. - CUZzolin, P.: Some linguistic and pragmatic remarks on the tabellae defixionum. Journal of Latin linguistics 15.2 (2016) 315-345. 
supposed to be enclosed, burn and fall into decay just like the dead man buried in the grave, where the tablet was located.

No. 1 from Rome, $d f x$ 1.4.4/13 ( $4^{\text {th }}-5^{\text {th }}$ cent. CE): Deprecor vos, sancti angeli. Quomodo (ha)ec anima intus in(cl)usa tenetur et angustiatur (=angustatur) (et) non vede (=videt) (ne)que (l)umine (=lumen), ne(que) a(li)quem (refri)gerium non (h)abet, si(c a)nima, (mentes, cor)pus Collecticii, quem pepe(rit) Agne(lla), teneatur, ard(eat), destabes(cat) (=detabescat). Usque (ad) infernum (se)mper $(d u)$ ci(t)e Collecticium, quem peperet (=peperit) Agnella.

I beg you, holy angels/daemons. Just like this soul is enclosed inside, ${ }^{11}$ imprisoned, and sees no light, nor has any recreation, may the soul, mind and body of Collecticius, whom Agnella bore, be equally enclosed, may it burn, and fall into decay. Lead Collecticius, whom Agnella bore, away as far as to hell.

\section{TAXONOMY OF VARIOUS TYPES OF CURSE TEXTS}

The motivation or occasion of roughly a half of the curses cannot be defined with certainty; therefore, these texts are classified as non-specific curses. ${ }^{12}$ Frequently, the detailed accounts of the body parts of a cursed person supposed to be afflicted by the curse occur, especially in the texts from Italy. The non-specific curses are preserved from all provinces of the Roman Empire, their widest spreading falls within the $1^{\text {st }}$ and $3^{\text {rd }}$ cent. CE.

See e.g. No. 2 from Carthage, $d f x$ 11.1.1/14 ( $1^{\text {st }}-3^{\text {rd }}$ cent. CE): Te rogo, qui infernales partes tenes, commendo tibi Iulia(m) Faustilla(m) Marii filia(m), ut eam celerius abducas et ibi in numerum tu(um) (h)a(b)ias (=habeas).

I ask you, who holds rule over the underworld, I commend you Iulia Faustilla, the daughter of Marius, so that you may take her as quickly as possible and have her in your number [of the dead].

Several curse tablets suggest that rivalry, envy, and animosity in some particular situations are the motives of their making. August Audollent classified the defixiones into four categories according to content as early as in 1904: defixiones iudiciariae, ago-

11 The exact location of the finding is unknown, see Solin, H.: Eine neue Fluchtafel aus Ostia. Commentationes humanarum litterarum, Societas scientiarum Fennica 42.3 (1968) 3-31, No. 34, who states that the inscription, which is damaged to a large extent, was painted with black colour on the inner side of a terracotta urn. See also KROPP, A.: Defixiones. Ein aktuelles Corpus lateinischer Fluchtafeln. Speyer 2008 [corpus abbreviation $d f x$ ] with completion of the text.

${ }^{12}$ KROPP (n. 11) uses a term Unspezifisch/Konkurrenz. 
nisticae, amatoriae and in fures. ${ }^{13}$ In the modern taxonomy a new category named as "prayers for justice" is now used for the texts; the category is only loosely identifiable with Audollent's curses in fures.

Legal curses (defixiones iudiciariae) are usually aimed at an opponent in court to eliminate his ability to think or speak during the process so that the author wins the lawsuit. This type of curses is well attested from all provinces of the Roman Empire, except for Britannia. It represents nearly $20 \%{ }^{14}$ of the preserved curse texts. The legal curses dated to the $1^{\text {st }}$ century CE come mostly from Germania; those dated to $2^{\text {nd }}$ or $3^{\text {rd }}$ cent. CE, were found in Africa; however, randomness of archaeological findings plays, no doubt, a huge role in this issue. See e. g.

No. 3 from Cordoba, $d f x$ 2.2.3/4 ( $1^{\text {st }}$ cent. BCE): Priamus l(ibertus) mutus sit omnibus modis. Hannue (=adnue), $n(e) q(u)$ is pos(s)it de (he)reditate verbum quet (=quod) facere, omnes o(b)mut(e)sq(ua)nt (=obmutescant), silient (= sileant?). ${ }^{15}$

May Priamus the freedman be mute in all ways. Grant that nobody is able to speak a word about the heritage, may they all be struck mute, may they be silent.

Agonistic curses (defixiones agonisticae) are aimed at rivals in circenses - gladiators, racers, charioteers and race-horses, and are predominantly supposed to limit their physical abilities and thus prevent them from winning. In some texts the whole horse riding teams are cursed which means that the most frequently cursed beings in antiquity were race-horses.

No. 4 from Hadrumetum, $d f x$ 11.2.1/22 ( $3^{\text {rd }}$ cent. CE), side B: Adiuro te demon, quicunque es, et demando tibi ex (h)anc (h)ora, ex (h)anc die, ex (h)oc momento, ut equos prasini et albi crucies, oc(c)idas et agitatore(s) Clarum et Felice $(m)$ et Primulum et Romanum oc(c)idas ... ${ }^{16}$

I adjure you, daemon, whoever you are, and I command you to torment and kill the horses of the green and white [teams] from this hour on, from this day on, and to kill Clarus, Felix, Primulus, and Romanus, the charioteers ...

${ }^{13}$ See Audollent, A.: Defixionum tabellae. Paris 1904, esp. p. LXXXIII; see also Kagarow, E.: Griechische Fluchtafeln [Eos Suppl. 4]. Lemberg-Paris, 1929, 28ff. as well. For the modern taxonomy see also FARAONE (n. 4) 3-5; KROPP, A.: Magische Sprachverwendung in Vulgärlateinischen Fluchtafeln. Tübingen 2008, esp. 186-192; Versnel, H. S.: Beyond Cursing: the Appeal to Justice in Judicial Prayers. In FARAONE-OBBINK (n. 4) 60-106; URBANOVÁ, D.: Latinské proklínací tabulky na území Řimského impéria. Brno 2014, see esp. 146-163 or URBANOVÁ, D.: Die lateinischen tabellae defixionum, der Usus und die Spezifika am Gebiet des römischen Reiches. In Molinelli, P. - CUZzolin, P. - FedRIANI, CH. (edd.). Latin vulgaire - Latin tardif X. Actes du Xe colloque international sur le latin vulgaire et tardif. Bergamo 2014a, Tome III, 1047-1098, see esp. 1070-1081.

${ }^{14}$ All the statistical data cited here are based on URBANOVÁ: Latinské proklínací tabulky (n. 13) $323 \mathrm{ff}$.

15 The reading CIL $\mathrm{II}^{2} 251 \mathrm{a}$, ne $q(u)$ is pos(s)it de (he)reditate/ silient/ quet hannue verbum /facere omnes omut[e]sq[ua]nt, I state the interpretation and word order suggested by KROPP (n. 11).

${ }^{16}$ For the whole text see KROPP's corpus (n. 11). 

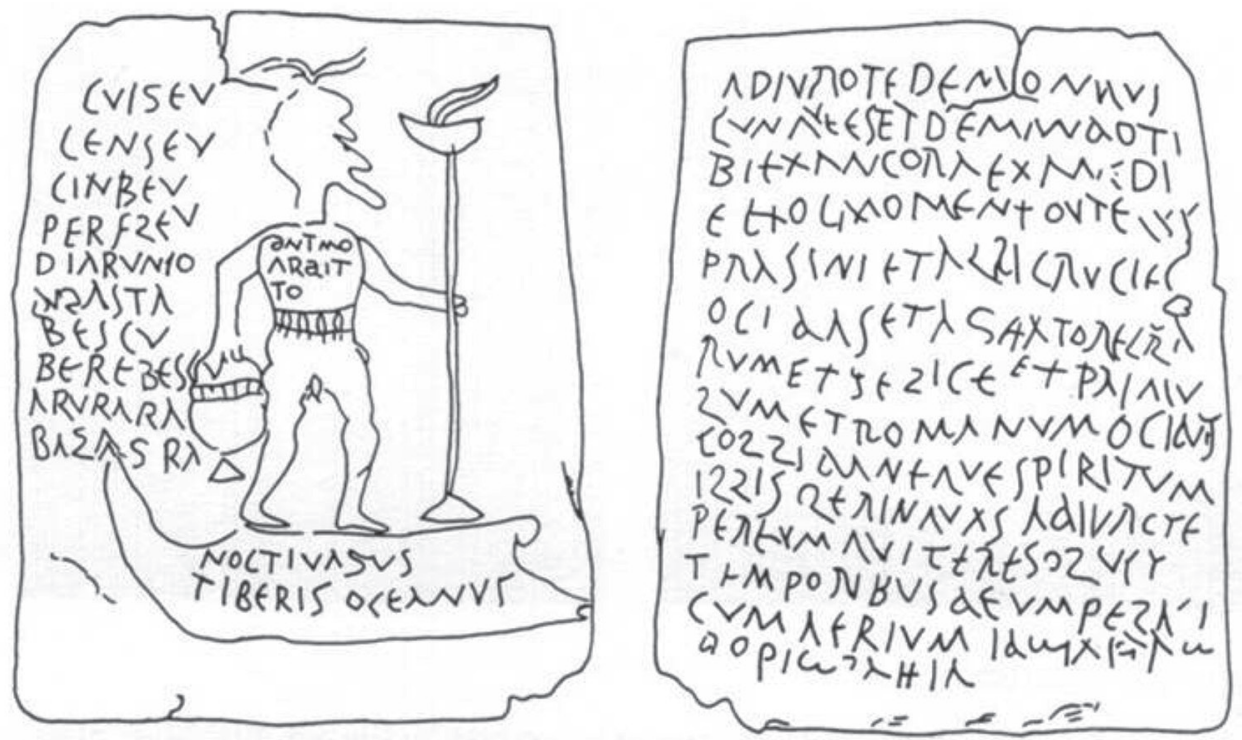

Picture 2. Facsimile of the tablet $d f x$ 11.2.1/22 from Hadrumetum, AUDOLLENT (n. 13) DT 286

On side A of the tablet, a long-bearded anthropomorphic daemon is depicted standing on a ship, holding an urn (?) in his right hand and a torch in his left hand. To the left of him, there are ten magical words written in a column: Cuigeu, Censeu, Cinbeu, Perfleu, Diarunco, Deasta, Bescu, Berbescu, Arurara, Baלagra; one more word is inscribed on the chest of the daemon: Antmoaraitto. The names of cursed hoses are inscribed on the depiction of the ship the daemon stands on: Noctivagus, Tiberis, Oceanus. The text of the curse itself is written on side B of the tablet. Agonistic texts represent (nearly 20\% of all texts we have $)^{17}$ in the preserved Latin curse documentation. All have been found in Africa and were often batch manufactured in local magical "workshops". These include many "magical" features (voces magicae, signa magica, see below) and date mostly to the $2^{\text {nd }}$ or $3^{\text {rd }}$ cent. CE. Although it can be presumed that this kind of curses was used in all regions of the Roman Empire where the circenses took place, only other types of curses have been found so far in other European amphitheatres; besides, agonistic spells from Rome written in Greek have been preserved.

Love spells (defixiones amatoriae) are associated with love and its desires. In love context, two types of defixiones appear: love spells ${ }^{18}$ meant to raise affection of a beloved person who is not returning author's affections - see No. 5, and curses delivered to harm a rival in love; see No. 6. Love spells pursue a temporary loss of intellectual capacity and bodily functions of the victim until the desired love is fulfilled

17 The data are based on URBANOVÁ (n. 13).

${ }^{18}$ See Faraone, CH. A.: Ancient Greek Love Magic. Harvard 1999. Esp. 41 ff., who uses Greek term $\alpha \gamma \omega \gamma \eta ́$, i.e. "a spell that leads", or attraction spell, German terminology uses term Herbeiführungszauber. 
(generally by coming at night to the house of the author). In contrast with the other types of curses, these usually contain the name of the author to make it clear who is supposed to be loved by the victim of the spell. The evidence of love spells securing success in love comes almost exclusively from Africa ${ }^{19}$ and most of it dates back to the $2^{\text {nd }}-3^{\text {rd }}$ cent. CE. This tablet contains a Latin text written in Greek alphabet, I cite here Audollent's transcription of the text (DT 270):

No. 5 from Hadrumetum, $d f x$ 11.2.1/8, DT 270 ( $2^{\text {nd }}$ cent. CE): Ad(iur)o ... per magnum deum et per (An)terotas ... et per eum, qui habet archeptorem (=accipitrem) supra caput et per septem stellas, ut, ex qua hora $(h)$ oc somposuero (=composuero), non dormiat Sextilios, Dionysi(a)e filius, uratur furens, non dormiat neque sedeat neque loquatur, sed in mentem (h)abiat me Septimam, Amene (=Amoenae) filia $(m)$; uratur furens amore et desiderio meo, anima et cor uratur Sextili, Dionysi(a)e filius (=filii), amore et desiderio meo. Septimes, Am(o)en(a)e fili(a)e. Tu autem Abar Barbarie Eloee Sabaoth Pachnouphy Pythipemi, fac Sextilium, Dionysi(a)e filium, ne somnum contingat, set amore et desiderio meo uratur, (h)uius spiritus et cor comburatur, omnia membra totius corporis Sextili, Dionysi(a)e filius (filii). Si minus, descendo in adytus Osyris et dissolvam $\tau \dot{\eta} v \tau \alpha \phi \eta \dot{\eta} v^{20}$ et mittam ut a flumine feratur; ego enim sum magnus decanus dei magni, dei AXRAMMACHALALA.E. ${ }^{21}$

I forswear you, the great god [i.e. Osiris], and Anterotes [Anteros is a daemon who revenges those abandoned and deceived in love], ${ }^{22}$ and the one with a hawk head [i.e. Horus, the Egyptian god of death], and the seven stars [i.e. planets], from the moment I put this tablet [into the grave], may Sextilius, son of Dionysia, not sleep, may he burn [with passion] in madness, may he not sleep, nor sit, nor speak, but bear in his mind me, Septima, daughter of Amoena; may he burn with love and longing for me, may the mind and heart of Sextilius, son of Dionysia, burn with love and longing for me, Septima, daughter of Amoena. And you, Abar, Barbarie, Eloe, Sabaoth, Pachnouphy, and Pythipemi, make Sextilius, son of Dionysia, unable to sleep, but burn with love and longing for me, may his spirit and heart, as well as all limbs of Sextilius' body be consumed by love: if not, I will descend into the shrine [grave] of Osiris, open his grave and throw him [into the river], so that he is carried away by the current; because I am the great decan of the god, mighty god AXRAMMAXALALA.E. ${ }^{23}$

\footnotetext{
${ }^{19}$ A recently found tablet from the fountain of Anna Perenna in Rome suggests also love context, see PIRANOMONTE (n. 7) 165; another potential exception is perhaps $d f x$ 7.4/1 from Raetia. But its text is unintelligible here and there.

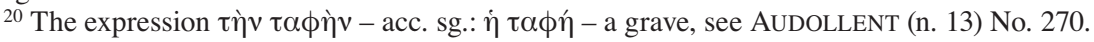

${ }^{21}$ For a commentary, see AUdollent (n. 13) No. 270.

22 See also Eros depictions on magical gems: MicHEL, S.: Die Magischen Gemmen. Zu Bildern und Zauberformeln auf geschnittenen Steinen der Antike und Neuzeit. Berlin 2004, 264-266.

${ }^{23}$ This is the only extant Latin love spell which was inscribed or ordered by a woman.
} 
Such texts contain a rich spectrum of specific bodily and mental restrictions meant to force the victim to fulfil author's wishes. As is proved especially by the Greek evidence, love spells were very popular - they represent a quarter of all Greek defixiones known today, and are attested already from the $4^{\text {th }}$ cent. BCE; this is contrasted by the preserved Latin love spells which constitute only $8 \%$ of the tablets known today. In the abovementioned tablet, Sextilius should be compelled to love Dionysia.

In this tablet we can observe also another phenomenon - the use of negation: the distribution of ne and non often seems to be random in the curse tablets. According to the general rules of Latin syntax, $n e$ is the conjunction that introduces negative volitional subordinate clauses like such as the final clause. This rule is well documented in tablets; however, in a huge number of cases the functions of the conjunction, which introduces the subordinate volitional clause and the negation, are separated: in this case $u t . . . n o n$ is found instead of $n e$, or it oscillates with ne, as in this tablet. This change demonstrates that ne was already being replaced by ut non. The situation is particularly interesting from a diatopic point of view. In my analysis this phenomenon occurs only in four inscriptions out of twenty five in the European Provinces: one in Italy, one in Gallia and two in Germania. The remaining twenty one cases appear in the tablets from Africa (thirteen instances) and Britannia (eight). The dating of these is remarkable, too: the European tablets date to the $1^{\text {st }}$ or $2^{\text {nd }}$ cent. $\mathrm{CE}$, whereas the African tablets all date to the period between the $2^{\text {nd }}$ and the $4^{\text {th }}$ century CE. ${ }^{24}$

The cases of rivalry in love (with the purpose of doing harm to a rival in love) are less conclusive, as it is not possible either to confirm or confute in all cases that the curse is really aimed at a rival in love. ${ }^{25}$ The following curses can be considered examples of rivalry in love: These texts come mainly from Italy, but some similar texts are preserved also in Hispania, Gallia and Germania.

See e.g. No. 6 from Mainz, $d f x$ 5.1.5/4; DTM $15^{26}\left(1^{\text {st }} / 2^{\text {nd }}\right.$ cent. CE): Prima Aemilia Narcissi agat, quidquid conabitur, quidquid aget, omnia illi inversum sit, amentita surgat, amentita suas res agat. Quidquid surget, omnia interversum surgat. (P)rima Narcissi aga(t): como haec carta nuncquam florescet, sic illa nuncquam quicquam florescat.

[Whatever] Aemilia Prima, [the lover?] of Narcissus may do, whatever she attempts, whatever she does, let it all go wrong. May she get up [out of bed] out of her senses/mind, may she go about her work out of her senses/ mind. Whatever she strives after, may her striving in all things be reversed. May this befall Prima, the lover of Narcissus: just as this letter never shall bloom, so she shall never bloom in any way. ${ }^{27}$

\footnotetext{
${ }^{24}$ See also URbANOVÁ-CUZZOLIN (n. 10).

${ }^{25}$ For further information on Greek source material, see also FARAONE (n. 18) 18.

${ }^{26}$ I state here the reading and interpretation BLÄNSDORF: Die defixionum tabellae (n. 1) No. 15.

27 See BLÄNSDORF: Die defixionum tabellae (n. 1) No. 15. The text is written counter-clockwise.
} 
The last extant category of curse texts represents the so-called prayers for justice. These texts were mostly aimed against thieves or persons who did some harm to their authors, which means usually against the unknown culprits of robberies. The term and taxonomy was introduced by $\mathrm{H}$. Versnel ${ }^{28}$ and is now generally used in scholarly literature. He defines these texts as pleas addressed to a god or gods to punish a (mostly unknown) person, who has wronged the author (by theft, slander, false accusations or magical action), often with the additional request to compensate the harm suffered by the author (for instance by forcing a thief to return a stolen object, or to publicly confess guilt). ${ }^{29}$ The author of the text cited below, Annianus, wants to get the stolen thing back, and, at the same time, seeks vengeance on the unknown culprit. Therefore, he is using the so-called "catch-them-all formula" utrum vir utrum femina...; (in other tablets from Britannia this formula prevalently appears with si (si puer, si puella...) and specifies to the goddess how she is supposed to afflict him or her.

See e. g. No. 7 from Bath, $d f x$ 3.2/77 ( $3^{\text {rd }} / 4^{\text {th }}$ cent. CE): A: Seu gen(tili)s seu ch(r)istianus, ${ }^{30}$ quaecumque (=quicumque), utrum vir, (u)trum mulier, utrum puer, utrum puella, utrum s(er)vus, utrum liber, mihi, Annia(n)o Mantutene (=Matutenae), de bursa mea s(e)x argente(o)s furaverit, tu, $d(o)$ mina dea, ab ipso perexi $(g)$ e (eo)s, si mihi per $(f)$ raudem aliquam inde praeg(u)stum dederit nec sic ipsi dona, sed ut sanguinem suum eputes (=epotes/ reputes, $)^{31}$ qui mihi hoc inrogaverit. ${ }^{32}$

Whether pagan or christian, whosoever, whether man or woman, whether boy or girl, whether slave or free, has stolen from me, Annianus (son of) Matutina?, six silver coins from my purse, you lady Goddess, are to exact [them] from him. If through some deceit he has given me ... and do not give thus to him, but reckon as? the blood//drink up the blood of him who has invoked this upon me.

${ }^{28}$ See VERSNEL: Beyond Cursing (n. 13) 60ff, esp. 90: „In the judicial prayer an individual, often giving his or her name supplicates the god(s) in a subservient way and asks for divine assistance in the form of retaliation for an injustice suffered." See also VERSNEL, H.: Prayers for Justice in East and West: Recent Finds and Publications. In Gordon, R. L. - Simón, F. M. (edd.) Magical Practice in the Latin West. Leiden 2010, 275-356.

${ }^{29}$ See VERSNEL: Beyond Cursing (n. 13) 60ff, and VERSNEL: Prayers (n. 28) 275-356.

30 The tablet dates back to the $3^{\text {rd }} / 4^{\text {th }}$ cent. CE, and TOMLIN: The Curse Tablets (n. 6) 233 argues that this is the first epigraphic evidence of the word christianus in Britannia.

31 Tomlin: The Curse Tablets (n. 6) 232-333 adds (r)eputes meaning "to settle a debt, pay off". VERSNEL: Beyond Cursing (n. 13) 89 and KropP (n.11) dfx 3.2/77 read epotes, i.e. "drink up!"; if it is so, the goddess Sulis (not explicitly named, but the tablet was found in the sacred spring in Bath) is to drink up culprit's blood as a punishment. No similar expression is attested elsewhere, despite the popularity of blood as the means of punishment in the texts from Britannia - sanguine suo solvat, redimat. The proper name Matuten $(a) e$ is probably a metronymic.

32 The nominal list of suspected persons follows: Postum(ianu?)s, Pisso, Locinna, (Al)auna, Materna, Gunsula, C(an)didina, Eutychius, Peregrinus, Latinus, Senicianus, Avitianus, Victor, Sco(tr)us, Aessicunia, Paltucca, Calliopis, Celerianus. For interpretation and translation of the text, see TOMLIN: The Curse Tablets (n. 6) No. 98. 
The delivery of such a tablet was not motivated by envy, or effort to harm an opponent, but by damage suffered - loss, theft, perjury. The structure of these texts in some respects differs from other types of curses. The culprits were obviously handed over to the deities to be punished. Prayers for justice comprise often of a name of the author, an address to a local deity, and they include also a motivation of the delivery of the prayer, usually a theft. More than a half of these are aimed at unknown culprits. Possibly, there is a list of detriments which are supposed to afflict the cursed one, if he does not return the stolen property or just a statement on the "rightful" vengeance. The taxonomy of this type of Latin and Greek curse texts has been considered by Versnel as slightly different from curses. Nevertheless, the term "prayers for justice" has been criticised by M. Dreher ${ }^{33}$ who proposes a new term defixiones criminales. My analysis of both categories and the aims and wishes of their authors shows that they are to a great extent similar. Both curses and prayers for justice use the same sort of means to afflict the victim, or the culprit; furthermore, the authors of prayers for justice frequently invent much crueller and more horrendous ways to afflict the culprits than the authors of other types of curses. ${ }^{34}$

This tablet shows us another interesting phenomenon of the curse texts especially from ancient Britannia - concerning the usage of the subjunctive mood. The subjunctive mood is used in the tablets according to the common rules of grammar. However, there is also a huge number of tablets in which forms like furaverit or involaverit $^{35}$ occur in relative clauses instead of the expected indicative mood. As for instance the text No. 7 quaecumque (=quicumque), utrum vir, (u)trum mulier, utrum puer, utrum puella, utrum s(er)vus, utrum liber, mihi, Annia(n)o Mantutene (=Matutenae), de bursa mea s(e)x argente(o)s furaverit. From a purely morphological point of view, the forms like furaverit, involaverit or pertulerit, used predominantly in the texts found in Britannia aimed against thieves, could be interpreted either as future perfect or perfect subjunctive. In the case of these curse texts these forms belong to the perfect subjunctive occurring also in the protasis of the hypothetical clauses and after donec in temporal clauses. The functional value exerted is that of the potential subjunctive. Unlike the syntactic tendency of Classical Latin, in which verb mostly occurs in the indicative mood when used with the indefinite-relative pronouns ending in -cumque or reduplicated like quisquis, the subjunctive mood prevails in these tablets (and significantly also in the legal language), thus the theft is stressed as a potential situation, as if the situation could be different.

Remarkable diversities in cursing practice can be found when comparing the preserved defixiones from particular provinces of the Roman Empire and their specific features. By now, about 90 tablets have been found in the territory of ancient Italy. ${ }^{36}$

\footnotetext{
${ }^{33}$ See Dreher, M.: "Prayers for Justice" and the Categorization of Curse Tablets. In PIRANOMONTE-SIMÓN: Contesti magici (n. 7) 29-32, see esp. 29-30.

${ }^{34}$ See URBANOVÁ:Latinské proklínací tabulky (n. 13)428-433 and, and URBANOVÁ:Die lateinische defixionum tabellae (n. 13) 107-108.

${ }^{35}$ See e.g. $d f x$ 3.2/10 from Bath; see Urbanová-CUZZOLIN (n. 10).

${ }^{36}$ KROPP's corpus (n. 11) includes 57 of them excluding those fragmentary or unintelligible ones published in AUdOLLENT (n. 13); 26 tablets come from the recent findings at the fountain of Anna Perenna in Rome, see BLÄNSDORF-PIRANOMONTE (n. 7) 617-639.
} 
The texts are dated from the $2^{\text {nd }}$ cent. BCE; compared to other provinces their number rises in the $1^{\text {st }}$ cent. $\mathrm{BCE}$ and $1^{\text {st }}$ cent. CE; most recently, the texts from the $3^{\text {rd }}-5^{\text {th }}$ cent. $\mathrm{CE}$ have been documented. The tablets from Italy are very diverse and variegated texts made both by the uneducated and the professionals in the field. They are typically found in graves or water sources, mostly scrolled and transfixed (that is the symbolical defigo "to fix, to strike"), or just scrolled. The non-specific and legal curses are the most common curse types in Italy. If some deities were addressed, it was usually the chthonic ones (Di inferi, Di Manes, Pluto, Proserpina, Cerberus, and nymphs). The texts from Italy contain a rich scale of cursing formulas, most frequently the type commendo ut pereant and trade morti filium, as anywhere else in the Empire. ${ }^{37}$ In most of the cases, men are the victims of curses; twice as many men as women are cursed in the tablets from Italy. As to the whole territory of the Roman Empire, the number of accursed men is three times higher than that of women. What is typical for Italy are the non-specific curses containing very detailed catalogues of all victim's body parts supposed to be afflicted by the curse. In addition, the authors seek to afflict victims' health and life and property in general. ${ }^{38}$

See e.g. No. 8 from Minturno, $d f x$ 1.4.1/1 ( $1^{\text {st }}$ cent. CE): Dii i(n)feri, vobis $\operatorname{com}(m) e(n) d o$, si quic $(q) u a(m)$ sactitates (= sanctitatis) h(a)betes (= habetis), ac tadro (= trado) Ticene (= Tychenem) Carisi, quodqu[o]d agat, quod incida(n)t omnia in adversa. Dii i(n)feri, vobis com(m)e(n)do il(l)ius mem(b)ra, colore $(m)$, figura $(m)$, caput, capilla (= capillos), umbra (m), cerebru(m), fru(n)te(m), supe(rcil)ia, os, nasu(m), me(n)tu(m), bucas, la[bra, ve]rba, (h)alitu(m), col(l)u(m), iocur, umeros, cor, pulmones, i(n)testinas (= intestina), ve $(n)$ tre $(m)$, brac(ch)ia, digitos, manus, $u(m) b(i)$ licu(m), visica (=vesicam), femena (= femina), genua, crura, talos, planta(s), ticidos (= digitos). Dii i $(n)$ feri, si illa $(m)$ videro tabesce $(n)$ te(m), vobis sacrificiu(m) lubens ob an(n)uversariu(m) facere dibus parentibus il(l)iu(s) voveo?...peculiu(m) ta(be)scas. (Transcription DT 190). Underworld gods, I commend to you, if you have any power whatsoever, and I entrust [to you] Tyche, wife/slave of Charisius, whatever she does, may everything turn against her. ${ }^{39}$ Underworld gods, I commend to you her limbs, hue, figure, head, hair, shade?/hair?, brain, forehead, eyebrows, mouth, nose, chin, cheeks, lips, words (=speech?), ${ }^{40}$ face, neck, liver,

${ }^{37}$ See Urbanová: Die lateinische defixionum tabellae (n. 13) 1081-1093.

${ }^{38}$ See also GoRdon, R. L.: 'What's in a list?' Listing in Greek and Graeco-Roman World. In Jordan, D. R. - Montgomery, H. - Thomassen, E. (eds.): The World of Ancient Magic. Bergen 1999, 239-277, esp. 270.

${ }^{39}$ See also FARAOne, CH. A. - Kropp, A.: Inversion, Adversion and Perversion as Strategies in Latin Curse-Tablets. In GORDON - SIMÓN (n. 28) 381-398, see esp. 384ff, formulae using the compounds of the verb verto.

${ }^{40}$ Another problematic part is la[bra, ve]rba (CIL), AUdOLLENT (n. 13) No. 190) reads la[bra, ve]rbum. The term verbum is associated with the function of lips and could thus be understood as "speech" or "ability to speak"; however, it is nowhere else attested in a similar context. Though legal curses often attack the ability to speak. 
shoulders, heart, lungs, bowels, belly, arms, fingers, hands, navel, bladder, thighs, knees, shins, ankles, feet, toes. Underworld gods, if I see her dying, I will gladly [offer] you that sacrifice [probably sacrificium should be added here] each year.")

The remaining text is damaged, it lacks a verb on which the infinitive facere depends, i.e. either voveo, as it is added in CIL (see above), or promitto "I promise". ${ }^{41}$ The next sequence is corrupted and unclear: Di parentes are the spirits of ancestors commemorated at the feast of the Parentalia. The offering refers to underworld gods, but the author at the same time promises a sacrifice to the spirits of ancestors. With respect to the disrupted state of the text, it cannot be figured out what or who illius refers to; it would be logical to link it with the text after lacuna: peculium tabescat, "may she disappear, may her, i.e. Tyche's, fortune vanish".

The tablet from Minturno dated to the first half of the $1^{\text {st }}$ cent. CE, which has been found scrolled and transfixed in a grave under the skull of the buried person. ${ }^{42}$ Although the text is not very damaged mechanically it contains plenty of Vulgar Latin features - the text can even be considered a representative list of typical phonological changes taking place in Vulgar Latin. The curse is aimed against Tyche (a freedwoman or a wife of Carisus) containing an extensive list of accursed body parts. The text starts with an address to the gods and the formula commendo ac trado. Then the author expresses a wish that whatever Tyche does may turn against her incidant omnia in adversa, further the body parts from head to heels are accursed. No expression repeats itself; the author explicitly asks for the death of the victim, the conclusion of the text is, unfortunately, damaged.

Here a small repetition of the typical Vulgar Latin features present in the above cited curse text, which are well attested in the curse tablets found in all parts of the Roman Empire. The particular regions do not differ extensively in this respect.

- interchange of e/i and o/u: habetes instead of habetis; fruntem instead of frontem

- omission of the final - $m$, -s: nasu - nasum, planta - plantas

- syncope: oclos for oculos, umblicu instead of umbilicum

- loss of geminate: bucas - buccas, colu - collum

- omission of $n$ before $s$, $f$ : iferi instead of inferi

- omission of nasals before occlusives: commendo-comedo, frute-frontem

- oscillation of grammatical gender: capilla-capillos; itestinas-intestina

- loss of the initial $h$ : alitu - halitum

- interchange of $c / g$ and $t / d$ : dicitod-digitos, ticidos - digitos

${ }^{41}$ Audollent (n. 13) No. 190 cites also other attempts at filling this free space.

${ }^{42}$ The tablet has been found together with a small marble woman statuette with combed hair, see Audollent (n. 13) No. 190, CIL X 8249, which perhaps symbolized the victim. 
The lists, be it of cursed persons or body parts, are considered to be firmly grounded in magical thinking. This is because the exhaustive list of items supposed to be afflicted, or of all possible outcomes, blocks all possibilities of the victim to escape. A similar anticipation of possible future situations is found in Roman legal documents. ${ }^{43}$ P. Poccetti $^{44}$ takes the enumeration of body parts as a language transposition of ritual procedure (the expression of Lat. defigo) which consists in the piercing of body parts, as we know it from the extant clay figurines called kolossoi. ${ }^{45}$

Five tablets with almost identical (damaged) texts containing cursing of body parts about hundred years older than the one against Tyche, written in "good Latin", including even some archaizing feature, come from Rome. These were found near Porta Salaria are dated to the half of the $1^{\text {st }}$ cent. BCE, and were published by W. S. Fox. ${ }^{46}$ The curses are written by the same hand and were probably made by a professional magician. The text of the curse could have been pre-made with spaces left to add the names of victims, which are altered in the particular tablets. This tablet accurses Plotius, it is one of the most complex curse type. The preserved text of the tablet with some additions made by W. S. Fox ${ }^{47}$ is the following:

No. 9 from Rome, $d f x 1.4 .4 / 8$ (first half of the $1^{\text {st }}$ cent. BCE):

A: Bona pulchra Proserpina, (P)lut(o)nis

uxsor, seive me Salviam deicere oportet, eripias salutem, co(rpus, co)lorem, vires, virtutes

Ploti. Tradas (Plutoni), viro tuo. Ni possit cogitationibus

sueis hoc vita(re. Tradas) illunc

febri quartan(a)e, t(ertian)ae, cottidia(n)ae,

quas (cum illo l)uct(ent, deluctent; illunc)

ev(in)cant, (vincant), us(que dum animam

eiu)s eripia(nt. Quare ha)nc victimam

tibi trad(o, Prose)rpi(na, seiv)e me

Proserpin(a, sei)ve m(e Ach)eruosiam dicere

${ }^{43}$ See Gordon (n. 38) 241-243.

${ }^{44}$ See PoCCETTI, P.: Manipolazione della realtà e manipolazione della lingua: alcuni aspetti dei testi magici dell'antichità. In MORRESI, R. (ed.): Linguaggio-Linguaggi. Invenzione-Scoperta. Roma 2002, 11-59, see esp. 26.

${ }^{45}$ See Faraone, CH. A.: Binding and Burying the Forces of Evil. The Defensive Use of "Voodoo-Dolls" in Ancient Greece. Class. Ant. 10 (1991) 165-205, esp. 18. See also GaGer, J. G.: Curse Tablets and Binding Spells from the Ancient World. Oxford 1992, esp. 98, and JÖRDENS, A.: Ritual für einen Liebes- und Bindezauber. In Untermann, M. (Hg.): Ägyptische Magie im Wandel der Zeiten. Universitätsmuseum Heidelberg 2011, 54-55.

${ }^{46}$ See FOX, W.: The Johns Hopkins Tabellae Defixionum [AJPh Suppl. Vol. 33]. Baltimore 1912. The tablets have been bought by the Department of Classical Archaeology of the Johns Hopkins University, Baltimore in 1908.

${ }^{47}$ See also the discussion on language peculiarities: RUíz, G. E.: Estudio linguistico de las defixiones latinas no includas en el corpus de Audollent. Emerita 35.2 (1967) 219-248, esp. 62 and 229; see also ERnout, A.: Recueil de textes latins archä̈ques. Paris 1957, No. 140; from the point of view of a votive ritual, see VERSNEL, H.: Two Types of Roman devotio. Mnemosyne 29 (1976) 367-410, esp. 399 ff. 
oportet. M(e mittas a)rcessitum canem tricepitem, qui (Ploti) cor eripiat.

Polliciarus illi te daturum t(r)es victimas palma(s, ca)rica(s), por(c)um nigrum hoc sei pe(rfe)cerit (ante mensem) M(artium. Haec, P)r(oserpina Salvia tibi dabo), cum compote(m) fe(cer)is. Do tibi cap(ut) Ploti Avon(iae. Pr)oserpina S(alvia), do tibi fron(tem Plo)ti. Proserpina Salvia, do (ti)b(i) su(percilia) Ploti. Proserpin(a) Salvia, do (tibi palpebra)s Plo(ti). Proserpina Sa(lvia, do tibi pupillas) Ploti. Proser(pina Salvia, do tibi nare)s, labra, or(iculas, nasu)m, lin(g)uam, dentes P(loti), ni dicere possit Plotius, quid (sibi dole)at: collum, umeros, bracchia, d(i)git(os, ni po)ssit aliquit se adiutare: (pe)c(tus, io)cinera, cor, pulmones, $n$ (i possit) senti(re), quit sibi doleat: (intes)tina, venter, um(b)ilicu(s), latera, (n)i p(oss)it dormire: scapulas, ni poss(i)t s(a)nus dormire: viscum sacrum, nei possit urinam facere: natis, anum, (fem)ina, genua, (crura), tibias, pe(des, talos, plantas, digito)s, unguis, ni po(ssit s)tare (sua vi)rt(u)te. Seive (plu)s, seive parvum scrip(tum fuerit), quomodo quicqu(id $)^{48}$ legitim(e scripsit), mandavit, seic ego Ploti ti(bi tr)ado, mando, ut tradas, (mandes men) se Februari(o) (e) cillunc.

B: Mal(e perdat, mal)e exset, (mal)e disperd(at. Mandes, tra)das, ni possit (ampliu)s ullum (mensem aspic)ere,

(videre, contempla)re.

Good, beautiful Proserpina, wife of Pluto, unless it would be fitting for me to call you Salvia, snatch away Plotius'health, body, complexion, strength, and abilities. Hand him over to Pluto, your husband so that he is unable

${ }^{48}$ For detailed discussion of the text see URBANOVÁ: Latinské proklínací tabulky (n. 13) 178-184; and URbAnOVÁ, D.: Contributi all'interpretazione di alcune tabellae defixionum. Graeco-Latina Brunensia 18.2 (2013) 187-197. 
to escape this [curse] by his wits. ${ }^{49}$ Hand him over to the fourth-day, the third-day, the daily fevers, ${ }^{50}$ let them wrestle and tussle with him, let them conquer and overwhelm him to the point that they snatch away his soul. Thus I consign him as a sacrifice to you, Proserpina, whether it would be fitting for me to call you Proserpina or Acherusia. ${ }^{51}$ Send me the threeheaded $\operatorname{dog}^{52}$ so that he rips out Plotius' heart. Promise him that you will give him three sacrifices: dates, figs, and a black pig, if he completes this before the month of March. These will I give you, Proserpina, when you have done for me as I have prayed.

I give you the head of Plotius, slave of Avonia, Proserpina Salvia.

I give you the forehead of Plotius, Proserpina Salvia.

I give you the eyebrows of Plotius, Proserpina Salvia.

I give you the eyelids of Plotius, Proserpina Salvia.

I give you the pupils of Plotius, Proserpina Salvia.

I give you the nostrils, lips, ears, nose, tongue, teeth of Plotius

so that he may be unable to speak about what afflicts him;

[I give you his] neck, shoulders, arms, fingers so that he may be unable to help himself in any way;

[his] chest, liver, heart, lungs so that he may be unable to know [the source of] what afflicts him;

[his] intestines, belly, navel, sides so that he may be unable to sleep;

[his] shoulder blades so that he may be unable to sleep soundly;

[his] intimate parts so that he may be unable to urinate;

[his] buttocks, anus, ${ }^{53}$ thighs, knees, legs, shins, feet, ankles, soles, toes, nails so that he may be unable to stand by his own strength;

Whether more or less has been written, just like someone has written this curse in a proper way [i.e. according to the magical precepts] ${ }^{54}$ and handed [it] over, so I hand over and consign Plotius to you, so that you may take charge of him by the month of February. Let him perish miserably, let him leave life miserably, let him be utterly wiped out miserably. Take charge [of him] and hand [him] over so that he may not consider, see, or contemplate another month. ${ }^{55}$

${ }^{49}$ Cogitatio probably means "the faculty of thought, reasoning of power" see Fox (n. 46) $36 \mathrm{ff}$.

50 This probably refers to the symptoms of malaria, see Fox (n. 46) 36.

${ }^{51}$ Acherusia is the epithet of Proserpina named after the river Acheron in the Underworld, metonymically also the Underworld itself.

52 Altogether seven curses from Italy are addressed to Cerberus, Pluto, and Proserpina.

${ }^{53}$ The term anus is quite rare in defixiones; apart from the five tablets from Rome, it occurs once more in the tablet from Bregenz $d f x$ 7.1/2: anum, genita(lia).

${ }^{54}$ See also VetTer, E.: Zu lateinischen Fluchtafeln. 1. Bleitafeln aus Minturnae. 2. Zu Johns Hopkins 'Tabellae defixionum'. Glotta 12 (1923) 65-67, who translates the relevant text in a similar way: "Sollte zu viel oder zu wenig geschrieben sein (nämlich von der Verfasserin der Defixion), so übergebe und überliefere ich dir den Plotius in solcher Weise, wie es gemacht hat wer richtig geschrieben und übergeben hat."

${ }^{55}$ For the interpretation of the end of the text see URBANOVÁ: Contributi (n. 48) 189-192. 
These five identical tablets are the most detailed extant texts of this type. They are not constrained just to the particular limbs, but also explicitly pursue to strike the bodily and mental functions of the victim related to the paralysis of the relevant body parts. The middle part of the curse describes the accurate process of commending the victim in parts to Proserpina and ends with the final wish: Let him perish miserably, let him leave life miserably, let him be utterly wiped out miserably.

The polite address bona pulchra Proserpina is somewhat peculiar when compared to other Latin epigraphical evidence. Similar polite addresses are typical rather of prayers for justice and do not very often appear in curses. They occur in curses especially if the daemons are addressed (sancti angeli, omnipotens daemon). The divine epithet bonus is found only in 24 inscriptions - either in the Latin tituli sacri or often enough in defixiones. The authors of curses usually, but not exclusively, use this epithet in connection with the chthonic deities, for example Proserpina, Di inferi, Diana and Attis. Other common epithets used in curses are sanctus and dominus. That means that the customs found in defixiones do not differ from common Latin sacred inscriptions. The use of these flattering epithets was obviously motivated by authors' effort to achieve the fulfilment of the curse through a special favour of the deity. ${ }^{56}$

Finally, the recently found (in Via Ostiense in 2003), extensive curse inscribed on both sides of the un-scrolled lead tablet, ${ }^{57}$ which has been dated to the $2^{\text {nd }}$ half of the $1^{\text {st }}$ cent. CE, appeals to the whole infernal procession. The victim of the curse, Caecilia Prima, is supposed to die a terrible death inflicted upon her by all invoked infernal powers according to their particular competencies. This is one of the most interesting and original extant curses; it reveals a literary education of its author, as it was written by someone with a very good knowledge of Latin, probably a professional. As to the literary value, this tablet has to be placed very high in the hypothetical rank of Graeco-Roman defixiones. Its context, however, is not clear; it was probably motivated by rivalry in love. ${ }^{58}$

No. 10 from Rome ( $2^{\text {nd }}$ half of the $1^{\text {st }}$ cent. CE):

Dite Pater, Proserpina Dia, Canes Orcini, Ustores inferi, Ossufragae, Larvae, Furiae, Maniae, Aves nocturnae, Aves Harpyiae, Ortygiae, Virga, Ximaera, Geryones, Siredonas, Circe, Gegantes, Spinx, vos precatur et petit, rogat vos, numina deum inferum, qui

${ }^{56}$ See EhMig, U.: Guter Gott! Bonus Deus in lateinischen Fluchtafeln. Graeco-Latina Brunensia 20.2 (2015) 3-9 states that the epithet bonus with the name of a deity is predominantly used for abstract notions like Bonus Eventus, or Mens, Valetudo, Dies, etc. (unless it constitutes a firm part of deity's name like e.g. Bona Dea, or almost exclusively Dacian god Bonus Puer (Phosphorus), or Bona Fortuna.

${ }^{57}$ Bevilaqua, G. - Colacicchi, O.: Una nuova defixio latina dalla via Ostiense. Notizie degli scavi d'antichità. Ser. IX, vol. XVII-XVIII, 2006-2007. Roma 2009, 303-349. See also BEVILACQUA, G.: Aurora Orchi soror. Parola del passato CCCLXIV (2009) 47-70.

${ }^{58}$ For the whole text with translation and commentary, see BEVILACQUA-COLACICCHI (n. 57) 305-327 and further BEVILACQUA (n. 57) 54ff. See also TheDeMa Nr. 517 (Thesaurus defixionum Magdeburgensis, online http://www-e.uni-magdeburg.de/defigo/wordpress/?page_id=6), English translation by S. Chiarini. 
suprascripti estis. Ea(m) Caeciliam Primam, sive quo

alio nomine est, uti eam,

Dite Pater, deprimas

malisque doloribus eam adpetas, aput te abducas.

Proserpina Dia, tu facias illam Caeciliam Primam,

sive quo alio nomine est, uti eam deprimas,

adimas illae sanguinem de venis, corpus, calorem

animi illae Caeciliae Primae eripias. Canes Or(c)ini,

Orcini tricipites, vos, illius Caeciliae Primae exedit(is) iocinera

pulmones, cor cum venis, viscera, membra, medullas,

eius diripiatis, dilaceretis, lumina eius $C(a)$ e(c)iliae $P(r)$ imae

a(d)ripiatis vosque Ustores inferi, eius Caeciliae

Primae peruratis lumina, stomachum,

cor eius, pulmones,

adipes, cetera membra omnia illius Caeciliae Primae,

peruratis, (a)duratis, vos, neque vivere nec valere possit...

Dispater, divine Proserpina, Ogre's Dogs, infernal Burners, Destroyers of bones, Larvae, Furies, Maniae, nocturnal Birds, Harpies, Ortygiae, Virga, Chimaera, Geryon,

Sirens, Circe, Giants, Sphinx: to you [he] prays and

implores, to you [he] begs, powers of the gods of the Underworld, who

have been mentioned above, that you, Dispater, knock down

that Caecilia Prima - or any other name she has -

and that you assail her with bad pains and take her away with you.

Divine Proserpina, may you knock down that Caecilia Prima

- or any other name she has -,

suck the blood from her veins, tear up the body and living

breath of that Caecilia Prima. Dogs of the Ogre,

three-headed Orcini, may you devour the liver of that Caecilia Prima,

her lungs, her heart with its veins, her innards, her limbs, her marrow,

may you tear them to pieces, may you pull out the eyes of that Caecilia

Prima and you, infernal Burners, may you set fire to the eyes of that

Caecilia Prima, to her stomach, heart, lungs,

to her fat and to all other body parts of that Caecilia Prima,

may you set on fire, burn to ashes, so that she cannot live or

be healthy ...

Apart from the usual couple of infernal deities, Pluto and Proserpina, other dark powers are invoked, too: canes Orcini the infernal dogs further referred to also as Orcini tricipites ${ }^{59}$ Ustores inferi infernal Burners of dead bodies; Ossufragae, ossifragus means

${ }^{59}$ For detailed discussion, see BEVILACQUA-COLACICCHI (n. 57) 305-327, Orcus is probably a variant of Dis Pater, or a place in the Underworld where the souls of the dead flow. 
"is qui ossa frangit"; Larvae the ghosts of the dead, apparitions (similar to umbrae) often mismatched for Lares and Manes; Furiae or Dirae, Erinyes, Harpyai, Maniae, the ominous, hostile, and malignant deities revenging the crimes; ${ }^{60}$ Aves nocturnae the bearers of ominous signs - bubo owl and ulula doom-monger, striges vampires. Aves Harpyae $^{61}$ the daemons of revenge; Ortygiae ${ }^{62}$ nowhere else attested; Virga that is a wand; ${ }^{63}$ Chimaera a three-headed monster ${ }^{64}$ spitting fire standing at the entrance to the Lake Avernus; Geryones ${ }^{65}$ monsters with three bodies. Siredonas probably Sirens thought to be the ghosts of the dead in ancient times, just like Harpies, Erinyes and Furies, the servants of Persephone whose job was to allure mortals and kill them; Kirké, here for the first time attested on a curse tablet; Gegantes the Giants; ${ }^{66}$ as well as Sfinx (the strangler) a legendary monster grabbing and strangling people. Further also Aurora soror Orci is addressed. ${ }^{67}$

Pluto is asked to take Caecilia Prima in pains with him to the Underworld, Proserpina is supposed to deprive her of the blood in her veins. The three-headed dogs are supposed to devour victim's liver, lungs, heart, etc., the infernal Burners to set fire to the eyes of Caecilia Prima, etc. The curse continues in this fashion and its core lies in the subsequent individual appeals to most of the invoked powers, invited to exercise their evil forces to the damage of Caecilia Prima. Caecilia is destined to die in a horrible way.

All the above mentioned curses come from Italy and date to the roughly same period: the curse against Tyche full of Vulgar Latin elements from Minturno dates to the first half of the $1^{\text {st }}$ cent. CE; the curse against Plotius from Rome written in good Latin and probably a professional work comes from the half of the $1^{\text {st }}$ cent. BCE; and the other curse from Rome also made by professional, invoking the whole infernal Pantheon is dated to the $2^{\text {nd }}$ half of the $1^{\text {st }}$ cent. CE. The stylistic and literary features applied demonstrate the significance of author's education in these texts. Generally, it can be said that the curses made in professional magical workshops are written predominantly in almost good Latin (many of these come from Italy and Africa) and include very complicated and stylistically elaborate formulations.

${ }^{60}$ Mania (sg.) is an old deity worshipped at Compitalia together with Lares; the mother of Manes and Larvae.

${ }^{61}$ Birds with female heads, originally the personifications of roaring winds, but also the daemons of revenge.

${ }^{62}$ In antiquity, a toponym associated to the sacred bird of Artemis coturnix-(quail); in this context, it probably refers to some mythical bird - nowhere else attested, see BEVILACQUA-COLACICCHI (n. 57) 312.

${ }^{63}$ Later in the text, it is addressed as a personification of some higher divine power - it is nowhere else attested, perhaps an equivalent of caduceus, the staff used by Hermes to summon the souls to the Underworld; Kirké also uses such a magical wand in Verg. Aen. VII, see BEVILACQUA-COLACICCHI (n. 57) 313.

${ }^{64}$ It has the head of a lion, a goat, and a snake; the daughter of Typhon.

65 The son of Oceanid Callirhoe and Chrysaor, born from the head of Medusa, Heracles took his cattle, which he guarded on the island of Erytheia; a two-headed dog Ortos, see BEVILACQUA-COLACICCHI (n. 57) 313.

66 The sons of Gé imprisoned in the rocks, who cause earthquakes and spit fire.

${ }^{67}$ The relation to Orcus is new - not attested elsewhere, see BEVILACQUA-COLACICCHI (n. 57) 309 and BEVILACQUA (n. 57) 50ff. 
A recent huge discovery of curse texts comes from Italy. In 1999 an ancient fountain was discovered in Rome including a cistern built around the spring and an adjacent reservoir. ${ }^{68}$ The two inscriptions with a dedication Nymphis sacratis Annae Perennae dated back to the $2^{\text {nd }}$ cent. CE suggest that the spring was related to the cult of this ancient Roman deity. The pottery found at the place indicates that the fountain was used from the $4^{\text {th }}$ cent. BCE up to the $6^{\text {th }}$ cent. CE. ${ }^{69}$ The rich archaeological findings lifted from the cistern yielded also a very precious material connected to the magical practices. The cistern was regarded a convenient place to deposit a curse, as it was a water source inhabited by water deities (nymphs) who could fulfil the wishes of those who cursed.

Oil lamps dated to the $4^{\text {th }}$ or $5^{\text {th }}$ cent. CE, were found, whereas at least 6 of the total number of 74 lamps were undoubtedly used as magical offerings. Small scrolled lead tablets were put inside them instead of a wick. The texts are quite damaged and contain impenetrable sequences of magical signs on one side; however, a typical, though a fragmentary, formula including the name of the victim and filiation via mother's name appears here. Three little lead slices with a curse against Victor, found in an oil lamp have been published by Blänsdorf. ${ }^{70}$ There have also been found 24 lead lidded cylindrical containers, hermetically sealed with a pitch. ${ }^{71}$ After these had been opened, two other smaller cylindrical containers were found placed one inside another, in some cases the tiniest vessels either had their own lids or were turned upside down. Some of these vessels even bear inscriptions and depictions of daemons. Very interesting is the depiction of the bird-headed daemon holding in his right hand an object, beside him there is a magical palindrome in Greek letters: AB $\Lambda$ ANA $\Theta A N A \Lambda B A$ associated with the Gnostic movements, and a solar religion. The Greek letters on the belly of the demonic figure: IXNOח/XNK/ $\Theta \Theta \Theta$ can be resolved as Iesous Xristos Nazarios $O$ Pais Xristos Nazarios Kai Theos, Theos, Theos. ${ }^{72}$

Seven of the vessels concealed anthropomorphic figurines made of organic materials like wax, flour, sugar, herbs, or milk; these symbolized the victims of the curses; the core of the figurines was made of animal bones. A very strange figurine has been found in the container with the depiction of the Egyptian god Seth. The figurine was made of an organic material, wrapped in lead, and transfixed with two nails, one

${ }^{68}$ Piranomonte, M. - Simón, F. M.: The Daemon and the nymph: Abrasax and Anna Perenna. Bollettino di archeologia 330 (2010) 1-16. See also PIRANOMONTE, M.: Religion and magic at Rome: the Fountain of Anna Perenna. In GoRdon-Simón (n. 28) 191-213, see esp. 191-192.

${ }^{69}$ PIRANOMONTE: Religion (n. 68) 192 and PirAnOMONTE: Un contesto magico (n. 7) 161.

${ }^{70}$ BLÄNSDORF, J.: The Texts from the Fons Annae Perennae. In GORDON-SIMÓN (n. 28) 215-244, see No. 6a, b, c. See also BLÄNSDORF-PIRANOMONTE (n.7) 617-639, esp. 631 and BLÄNSDORF: The Social Background (n. 7) 147-160, esp. p. 155.

${ }^{71}$ PiRAnOMONTE: Religion (n. 68) 205, and PiRAnOMONTE: Un contesto magico (n. 7) 161ff.

72 See BlÄNSDORF-PIRANOMONTE (n. 7) 619 and PIRANOMONTE: Religion (n. 68) 171; for the interpretation of the Greek letters on the belly, see NÉMETH, G.: Jesus in Ancient Pagan Magic: The Anna Perenna Drawings. In BAKowsKA-CzERnER, G. - RocCATI, A. - ŚwIERZOWSKA, A. (eds.): The Wisdom of Thoth. Magical Texts in Ancient Mediterranean Civilisation. Oxford 2015, 55-60. 
in its legs and another in its belly. The snake seems to clasp the body of the figurine and bite it in the face. ${ }^{73}$

Moreover, other 26 mostly lead tablets have been found in the cistern containing curses. ${ }^{74}$ One of them - defixio with Christ and Nymphs $\left(4^{\text {th }} / 5^{\text {th }}\right.$ cent. CE), although largely disrupted, floats between Paganism and Christianity.

No. 11 from Rome $\left(4^{\text {th }} / 5^{\text {th }}\right.$ cent. CE):

... conatas suas person(as)...ill...

et uaticolo m.l...erio...

filio et quisquis .c.rm...

(roga)mus cras deas uest(ra)s...

et cristum nostr(um) ...

(Qui) gaudent timi(a)nt t...

eu(m) uincam i...c...

...suc.ui ...

If Blänsdorf's ${ }^{75}$ reading and interpretation are correct, the author of the tablet was a Christian who did not hesitate to use all means available to achieve his goal. The beginning of the tablet is very damaged, but in the $4^{\text {th }}$ line and further, we can read the sequence (roga)mus cras deas uest[ra]s ... et cristum nostr(um) ... (Qui) gaudent timi(a)nt $t . . e u(m)$ uincam .... "we will ask tomorrow your goddesses ... and our Christ ... Those who rejoice, shall fear, I shall defeat him ...?"

The most preserved and longest defixio found in the fountain is perhaps the curse against Sura. The text is framed on both sides with vertical lines and four snake-like figures with small heads and open mouths resembling beaks, which are joined together in the middle. Magical signs are found above the text, on the sides between the snakes, and also below the text. In the middle of the text, there is a rhombus filled with a schematically drawn face imposed on a thick neck and a limbless cello-shaped body. The top of figure's head is marked by four vertical strokes perhaps symbolizing a crown. ${ }^{76}$

No. 12 from Rome $\left(4^{\text {th }} / 5^{\text {th }}\right.$ cent. CE):

Sacras santas a supteris ${ }^{77}$ et angilis quod rogo et peto magnam virtutem vestram: tollatis pertollatis oculus (=oculos) sive dextrum et sinesteru(m) Surae, qui na(tus) maledicta modo ets (=est) de vulva. Fiat rogo et

${ }^{73}$ PiRANOMONTE-SimÓN: The Daemon (n. 68) 9.

${ }^{74}$ PIRANOMONTE: Religion (n. 68) 164.

75 BLÄNSDORF-PIRANOMONTE (n. 7) 629.

${ }^{76}$ PIRANOMONTE: Religion (n. 68) 211 considers the central rhombus to be a depiction of a vagina and interprets the figure inside the rhombus as a symbolic depiction of the goddess Anna Perenna. See BLÄNSDORF: The Texts (n. 70) 215-244, is inclined (p. 226) to believe that the figure depicts some kind of daemon instead, and finally BLÄNSDORF: The Social Background (n. 7) 633 states that there is the judge Sura as a new born child in the rhombus.

77 Supteris was perhaps created analogically according to superis, i.e. inferis, see BLÄNSDORF: The Texts (n. 70) 239. 
peto magnam virtutem vestra(m). Tollite oculus dextru sinisteru ne possit durare virtus arbitri Surae, qui natu(s) est de vulva maledicta.

Sacred, holy [nymphs], through the underworld [gods?] and daemons I wish and demand from your great virtue: remove, utterly remove the eyes, either the right one or the left one, of Sura, who was born from a cursed womb. ${ }^{78}$ I wish and demand from your great virtue that it shall happen, take the eyes, the right one and the left one, so that the virtue of Sura the judge, born from a cursed womb may not persist.

The content suggests that this curse has been made in a legal context - arbiter was the state official in the Dominate whose job was to help the judge prepare the legal procedure and secure the evidence. ${ }^{79}$ While the tablets found in Italy are a mixture of various types of texts written by laymen as well as professionals, the extant evidence from other parts of the Roman Empire is often substantially different.

The evidence of curses in the African provinces is very rich and diverse; altogether about 80 tablets have been preserved. Unlike the European provinces, these are of later date - more than two thirds of the tablets have been (not very precisely) dated to the $2^{\text {nd }}$ or $3^{\text {rd }}$ century CE. The frequent occurrence of curse tablets in this period is probably associated with the considerable influx of Romans to the African provinces taking place at the time. Most of the tablets have been found in graves, often scrolled, some of them in the amphitheatre of Carthage. Men are four times more often accursed than woman, which is related to the predominance of legal and agonistic curses. However, the most frequent victims of African curse tablets are horses - their number by far exceed the numbers of accursed persons (about 1200). The number of formulas used in the tablets is relatively high, as mostly the more complicated curses have been found in the African provinces; the magicians frequently use the imperative formulas to make the deities do whatever the author wishes. Almost all types of curses have been preserved in Africa, except for the texts connected to rivalry in love and prayers for justice. In comparison with the European provinces, there are relatively few non-specific curses in Africa; legal curses are more frequent; whereas almost all Latin love spells and agonistic curses we have, have been found in the African provinces. ${ }^{80} \mathrm{~A}$ substantial part of these were obviously made in the workshops of professional magicians. Unlike the European provinces, the authors usually appeal to daemons, addressing them via magic formulas. These curses include formulations referring to magical papyri influenced by Greek and Egyptian tradition and other magical features like voces magicae or signa magica. Very often we find a non-standard orientation of script, or a combination of Greek alphabet and Latin letters, or Latin texts written in Greek letters - to put it briefly, the African curses very often possess a magical layout.

${ }^{78}$ I. e. mother. The mother's name, if it is unknown, it is usually replaced with vulva in defixiones.

${ }^{79}$ BLÄNSDORF: The Texts (n. 70) 224.

${ }^{80}$ We have agonistic spells from Rome written in Greek, see e. g. TREMEL, J.: Magica Agonistica. Fluchtafeln im antiken Sport. Hildesheim 2004. 
See e. g. No. 13 from Hadrumetum, $d f x$ 11.2.1/5 (without dating) a love

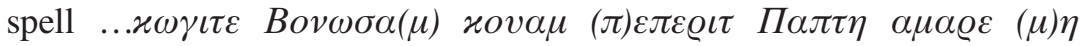

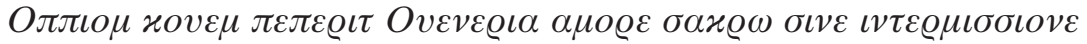

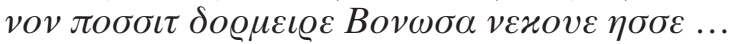

it is a Latin text written in Greek alphabet:

... cogite Bonosa(m), quam (p)eperit Papte, amare (m)e, Oppium, quem peperit Veneria, amore sacro sine intermissione, non possit dormire Bonosa neque esse ...

... make Bonosa, daughter of Papte, love me, Oppius, son of Veneria, unceasingly with sacred love, may she be unable to sleep or eat ..."81

The next tablet from Carthage is one of the best examples of the text's magical treatment; it is written mostly in Greek (especially the magical words and formulas), partially in Latin, and is framed by magical signs. The curse is aimed at a gladiator named Vincenzus Zarizo; the Late Latin assibilation of $d i$ and $t i$ pronounced as $[\mathrm{z}, \mathrm{dz}]$ is reflected here (written on inscriptions as Z, or also as $\zeta$ ), Vincentzo - Vincentius, Gie (=die); moreover, there is reduplication of consonants in Merccuri, urssum.

No. 14 from Carthage, $d f x$ 11.1.1/28 ( $2^{\text {nd }}$ cent. CE) curse against gladiator: ...in Vincent\}o TYarit\}oni quen peperit Con(cor)dia in ampit\}atru Carthaginis in Gie (=die) Merccuri obligate, in(p)licate lac(i)nia Vin-

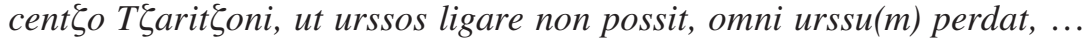
non occidere possit in לie Merccuri in omni ora iam iam, cito cito, facite ... against Vincenzus Zarizo, who was born from Concordia, in the amphitheatre of Carthage on Wednesday, bind [him], entangle the nets of Vincenzus Zarizo, may he be unable to chain bears, may he lose with every bear, ... may he be unable to kill [a bear] on Wednesday, in any hour, now, now, quickly, quickly, make it happen ... ${ }^{82}$

To sum up, the texts coming from the African provinces substantially differ from those found in the other parts of the Roman Empire where professional magicians appeared only rarely, perhaps only with the exception of Italy.

The Mediterranean cursing practice spread also to the most western part of the Roman Empire, Britannia; this is clear from the rich documentation of defixiones in this area. However, the situation here is somewhat different. About 160 tablets have been published out of the overall number of about 270 tablets found. More than a hundred of these are prayers for justice aimed against thieves. The tablets have mostly

${ }^{81}$ For the whole text, see Audollent (n. 13) No. 267; Kropp (n. 11) No. $d f x 11.2 .1 / 5$.

${ }^{82}$ For the whole text, see Audollent (n. 13) No. 253; Kropp (n. 11) No. $d f x$ 11.1.1/28; TrEMEL (n. 80) No. 99; URBANOVÁ (n. 13) No. 135. 
been found at shrines or in the places connected to water in the city of Bath and the holy precinct of Mercury in Uley. The texts have been dated from the $1^{\text {st }}$ to the $5^{\text {th }}$ cent. $\mathrm{CE}$, most of them come from the period between the $2^{\text {nd }}$ and $4^{\text {th }}$ cent. CE. Unlike the evidence coming from other provinces, the texts of curses found in Britain are very brief and consist predominantly of nominal lists of the accursed persons. They do not contain any magical words, names of daemons, or magical signs, whether in Greek or Latin. Magical features appear only graphically, that is in the form of a non-standard orientation of script (mostly right-to-left). The contrast between the brief and artless phrasing of the curses from Britannia and the figurative and elaborate language of the prayers for justice from the same area is remarkable. The authors of prayers for justice from Britannia most frequently address the local deities and seek only "a rightful vengeance", that means a punishment of the culprit; only a third of the texts want to achieve also the returning of the stolen property together with the punishment of a mostly unknown culprit. They do so in a way identical to curses. Especially in the texts from Germania and Britannia, we notice a certain blending of the two categories, when curses and prayers for justice are perceived in a similar way.

See e. g. No. 15 from Bath, $d f x$ 3.2/76 ( $3^{\text {rd }} / 4^{\text {th }}$ cent. CE): Basilia donat in templum Martis anilum (=anellum) argenteum, si ser(v)us, si liber, m(e)dius/(ta)mdiu ${ }^{83}$ fuerit vel aliquid de hoc noverit, ut sanguine et liminibus (=luminibus) et omnibus membris configatur vel etiam intestinis excomesis (om)nibus habe(at) (=intestina excomesa omnia) is, qui anilum (=anellum) involavit vel qui medius fuerit.

Basilia gives [in] to the temple of Mars [her] silver ring, that so long as [someone] whether slave or free, keeps silent or knows anything about it, he may be accursed in [his] blood and eyes and every limb, or even have all [his] intestines quite eaten away, if he has stolen the ring or been privy to [the theft]. ${ }^{84}$

Promises to the gods are found more frequently in prayers for justice, though not in the same form as vota in curses - the author promises a finder's reward to the deity that means a part of the stolen property or money, if he gets it back. ${ }^{85}$

See e. g. No. 16 from Uley, $d f x$ 3. 22/3 ( $2^{\text {nd }}-4^{\text {th }}$ cent. CE): Commonitorium deo Mercurio a Saturnina muliere de lintiamine (=linteamine), quod amisit, ut ille, qui ho(c) circumvenit, non ante laxetur, nissi quand(o) res s(upra)dictas ad fanum s(upra)d(ic)tum attul(e)rit, si vir si (mu)lier, si servus si liber. Deo s(upra)dicto tertiam partem (d)onat, ita ut exsigat istas

\footnotetext{
${ }^{83}$ See Tomlin: The Curse Tablets (n. 6) No. 97, adds tamdiu, KROPP (n. 11) $d f x$ 3.2/76 adds medius.

${ }^{84}$ See TomLin: The Curse Tablets (n. 6) No. 97 for the interpretation and translation.

85 See also KropP (n. 13) $164 \mathrm{f}$.
} 
res, quae s(upra)s(crip)ta(e) sunt ac a quae per(didi)t. Deo Silvano tertia pars donatur, ita ut hoc exsigat, si vir, si femina, si servus, si liber ...

A memorandum to the god ... Mercury ${ }^{86}$ from Saturnina, a woman, concerning the linen cloth which she has lost. [She asks] that he who has stolen it should not have rest, before/unless/until he brings the aforesaid property to the aforesaid temple, whether man or woman, whether slave or free. She gives a third part to the aforesaid god on condition that he exacts this property which has been written above. A third part ... what she has lost is given to the God Silvanus on condition that he exact it, whether man or woman, whether slave or free ..." ${ }^{87}$

In the tablets found in Britannia, specific wishes of the authors pursuing culprit's death are represented by formulations nowhere else attested in the Latin production. This concerns the formula sanguine suo redimere or satisfacere, which is with some alternations and often combined with other penalties attested in altogether 20 tablets. ${ }^{88}$

See e. g. No. 17 from Bath, $d f x$ 3.2/79 ( $3^{\text {rd }} / 4^{\text {th }}$ cent. CE): Minerv(a)e de(ae) Suli donavi furem, qui caracallam meam involavit, si ser(v)us, si liber, si baro, si mulier. Hoc donum non redemat, nessi (=nisi) sangu(i)n(e) suo. To Minerva the goddess Sulis I have given the thief who has stolen my hooded cloak, whether slave or free, whether man or woman. He is not to buy back this gift unless with his own blood. ${ }^{89}$

As for the cruel and bizarre wishes of the authors of prayers for justice mentioned in the tablets, I cannot omit the texts which seek vengeance in the form of the culprit being devoured by worms, documented only in the two tablets from Germania.

See e. g. No. 18 from Gross-Gerau, $d f x$ 5.1.3/2 (1 $1^{\text {st }}$ cent. CE): (H)umanum quis sustulit Verionis palliolum sive res illius, qui illius minus fecit, ut illius mentes, memorias deiectas sive mulierem sive eas (-eam), cuius (-quae) Verionis res minus fecit, ut illius manus, caput, pedes vermes, cancer, vermitudo interet, membra medullas illius interet.

\footnotetext{
${ }^{86}$ The name of god Mercury was written over another name of god Mars Silvanus who is, nevertheless, mentioned once more in the tablet; the tablet has been found in the sacred precinct of Mercury. Perhaps it is a Roman identification with s local deity) see ToMLIN: The Inscribed Lead Tablets (n. 5) 120.

${ }^{87}$ Translation by TomLIN: The Inscribed Lead Tablets (n. 5) 121. About 40 curse tablets from Uley are to be published soon by Tomlin.

${ }^{88}$ See URBANOVÁ: Die lateinische defixionum tabellae (n. 13) 1063-1081.

89 The interpretation and translation by ToMLIN: The Curse Tablets (n. 6) No. 65.
} 
The human who stole Verio's cloak or his things, who deprived him of his property, may he be bereft of his mind and memory, be it a woman or those who deprived Verio of his property, may the worms, cancer and maggots penetrate his hands, head, feet, as well as his limbs and marrows. ${ }^{90}$

The evidence of defixiones preserved in the area of the Roman Empire is a rich mixture of texts either made by professionals, which have been found in the African provinces and include complicated magical apparatus, or the texts found in all other parts of the Roman Empire. Only in Italy some texts resembling these professional works can be found. Unfortunately, not very many defixiones have preserved in Gallia or Hispania. Remarkably, in the northern provinces of Noricum, Raetia, Germania Superior, and Pannonia, the Mediterranean magical tradition blended with local religious customs which resulted in some very interesting and original adaptations. Especially the recent findings at the votive depository of Mater Magna's and Attis' temple in Mainz confirm the process of combining the formulas typical of curses and prayers for justice. Furthermore, several intriguing and nowhere else attested adaptations of traditional cursing practices have been found here, similarly to the peculiar prayers for justice from Britannia. Tracing the features of Vulgar Latin ${ }^{91}$ is, however, very challenging, as these seem to occur in tablets in a very diffuse and random way. Moreover, in most of the cases we do not even know the authors' names (only the names of victims are stated) so it cannot be said whether the authors were from the particular region or whether they came from somewhere else. Likewise, the large number of people migrating together with Roman legions has to be taken into account, too, as the ethnic structure of these was very diverse and included the merchants and magicians from all over the Roman Empire.

It seems that either the authors sought the services of professionals or there were probably model texts of prayers for justice in circulation, as in Britannia. ${ }^{92}$ These were then completed with the specific information regarding the cases of particular people. Nevertheless, we cannot forget that the corpus of preserved defixiones is largely fragmentary; thus, our knowledge of ancient cursing tradition has to be fragmentary, too. Recently, 270 tablets have been found during the archaeological excavations at

${ }^{90}$ See BLÄNSDORF, J.: ‘Würmer und Krebs sollen ihn befallen': Eine neue Fluchtafel aus Gross-Gerau. ZPE 161 (2007) 61-65 with commentary 62ff., who assumes that an assault or devourment by worms was one of the most gruesome kinds of death that could be imagined in antiquity. For the specific features of curse texts from Germania see URBANOVÁ, D.: Die Sprache der Fluchtafeln aus Germania, Noricum und Raetia. Studia Latina Upsaliensia 35 (2015) 597-610.

${ }^{91}$ See the new "Computerized Historical Linguistic Database of Latin Inscriptions of the Imperial Age" (http://lldb.elte.hu/) and ADAMIK, B.: In memoriam József Herman: von der Late Latin Database bis zur Computerized historical linguistic database of Latin inscriptions of the Imperial age. Acta Ant. Hung. 49 (2009) 11-22.

${ }^{92}$ As it is attested in the tablet from Bath $d f x$ 3.2/8, see TomLin: The Curse Tablets (n. 6) No. 8, where at the end of the curse is written: carta picta persc(ripta) - "the written page [has] been copied out". Tomlin states that carta picta perscripta evidently indicates that the author copied the formula of the curse from some model tablet. In this context "carta" means a lead tablet. 
the two shrines in Britannia, and 34 tablets in Mainz, but these are all marginal areas of the Roman Empire. In the territory of Italy, only 90 tablets have been found so far. However, this kind of magic must have been practiced here much longer than in the provinces, as is clear from The Laws of Twelve Tables which specify sanctions against curses. Therefore, it is obvious that the extant tablets do not provide us with a real image of the contemporary cursing tradition; rather they give us a rough idea of how many texts have not been found yet or are lost forever. To put it briefly, the analysis of Roman curse tablets often brings more questions than answers. ${ }^{93}$

Daniela Urbanová

Department of Classical Studies

Masaryk University, Faculty of Arts

A. Nováka 1

CZ-602 00 Brno

Czech Republic

urbanova@phil.muni.cz

${ }^{93}$ My grateful thanks for the English translation of the whole text of this article and especially for the translation of my Czech interpretations of the tablets No. 1, 2, 3, 5, 8, 12, 13, 14 go to my dear colleague Natália Gachallová. 